\title{
Control Power of Senior Executive, Business Environment and Entrepreneurship
}

\author{
Liyan Zhang*, Chengzi Cao
}

School of Business Administration, Shanxi University of Finance and Economics, Taiyuan 030006, China

Corresponding Author Email: zhly@sxufe.edu.cn

https://doi.org/10.18280/ijsdp.150717

Received: 1 April 2020

Accepted: 23 August 2020

\section{Keywords:}

control power, senior executives, business environment, entrepreneurship

\begin{abstract}
Senior executives have the power to formulate and implement strategic decisions of their company. Entrepreneurship is the critical human capital owned by them. To stimulate entrepreneurship, it is important to ensure that the company is controlled by senior executives with entrepreneurial spirit. Taking China's A-share listed companies in 2013-2018 as the objects, this paper discusses the influence of control power of senior executives (executive control) over entrepreneurship, and further explores how each dimension of business environment and their interactions affect executive control and entrepreneurship. The results show that executive control greatly promotes entrepreneurship; high legalization level and intense market competition are favorable for entrepreneurship. The incentive effect of executive control on entrepreneurship can be enhanced by government intervention and market competition, and greatly bolstered through the interaction between legalization level and government intervention, as well as the interaction between market competition and government intervention.
\end{abstract}

\section{INTRODUCTION}

China is vigorously pursuing high-quality development (HQD), that is, transforming labor- and capital-driven economy into innovation-driven economy. Under the HQD, the primary innovators are companies, whose entrepreneurs have extraordinary abilities and entrepreneurial spirit.

Senior executives have the power to formulate and implement strategic decisions of their company. Entrepreneurship is the critical human capital owned by them. It directly reflects the ability of senior executives to correctly understand the situation of the company, and shapes the internal and external environment of corporate governance. To stimulate entrepreneurship, it is important to ensure that the company is controlled by senior executives with entrepreneurial spirit.

The efficiency of entrepreneurs hinges on the allocation of internal power, a scare resource in the company. Entrepreneurs are eager to make their companies larger and stronger by sharing equity. But they also worry about losing the control over their companies through equity dispersion. In modern corporate governance, it is a key issue to design an incentive mechanism around control power, which integrates the interests of shareholders with the personal interests of entrepreneurs.

Entrepreneurship is the result of the current society, economy, and culture. Without well-developed market economy or institutional environment, it is impossible for senior executives to acquire the entrepreneurial spirit $[1,2]$, not to mention making entrepreneurship a useful resource. The role of entrepreneurship depends on the institutional factor of business environment. If the business environment is good, the power allocation will be rationalized to promote innovation and entrepreneurship. Of course, the difference in entrepreneurship between companies in the same business environment cannot be fully understood based on business environment alone. Therefore, entrepreneurship stems from the interaction between corporate governance and corporate governance.

Through the above analysis, this paper analyses the control power of senior executives (executive power), business environment, and entrepreneurship under a unified framework. Targeting China's A-share listed companies in 2013-2018, the authors investigated the correlations between executive power, business environment, and entrepreneurship, and evaluated the influencing factors of entrepreneurship from the institutional perspective.

There are three innovations in this research: (1) The incentive mechanism of executive control for entrepreneurship was explored deeply from the angles of incentives and constraints, and its influence was clarified through empirical analysis. (2) The influence of business environment on entrepreneurship was discussed from each of its three dimensions and from the interactions among these dimensions, providing new evidence to how business environment affects entrepreneurship. (3) Business environment was introduced to a research framework about the influence of executive power on entrepreneurship, which explains why the companies in the same business environment differ sharply in entrepreneurship.

\section{THEORETICAL ANALYSIS AND RESEARCH HYPOTHESIS}

2.1 The control power of senior executives and entrepreneurship

During the operation of a company, the compensation 
system of control power mainly consists of monetary gains and untransferable private gains. Thus, the key components of the incentive mechanism of entrepreneurs include control power incentive and salary incentive.

For any company, the allocation of control power often favors senior executives, due to historical and realistic factors [3]. Compared with shareholders, senior executives possessing relationship resources and knowledge-based resources boast a huge control power over the company. They can directly regulate the management flow and coordinate the innovation resources of the company $[4,5]$.

Possessing the control over corporate operations is the premise for entrepreneurs to develop administrative ability. Through operational control, entrepreneurs can enjoy the return of monetary compensation and non-monetary reward [6].

At present, there are two opposite views about the influence of executive power on entrepreneurship. Some scholars held that executive power promotes the nurture of entrepreneurship: For financial benefits and personal stature, senior executives will utilize their power and social capital to make the company invest more in innovation and enhance the company's capability of technological innovation; the innovation activities obviously contribute to the cultivation of entrepreneurship [7]. Some other scholars argued that executive power suppresses the development of entrepreneurship: For personal values and self-interests, senior executives will utilize their power and make decisions to seek private benefits at the cost of company development [8].

Most of the existing studies on executive power and entrepreneurship start from the two-sidedness of the incentive effect of control power, failing to consider that the behaviors of senior executives are constrained by shareholders, the board, and even external institutional environment. To fully understand the merits and defects of the incentive mechanism of entrepreneurs, both incentives and constraints should be taken into account to study the influence of executive power on entrepreneurship.

Since power always brings benefits, control power has an implicit incentive mechanism. Apart from salary, control power gives entrepreneurs various implicit incentives, namely, self-realisation, holding rights, and material interests [2]. Together, these incentives constitute the return for the efforts and contributions of entrepreneurs. To acquire more benefits, entrepreneurs tend to pursue greater control power, and invest more in innovation [9].

The incentive effect of control power depends on the degree of symmetry between the contribution and control power of entrepreneurs [2]. If the contribution is smaller than control power, an entrepreneur will make greater efforts with the growing incentive strength. If the contribution is greater than control power, the entrepreneur will pursue greater control power to match his/her contribution.

The control power allows senior executives to determine their salary and reap private benefits. Therefore, the influence of executive power on entrepreneurship is a kind of principalagent problem. As per the logic of control power allocation, however, the control power and its degree are determined by the board, who can restrain the self-serving behaviors of senior executives. In this way, the behaviors of senior executives are further restrained by the psychological cognitions and values of managers on company decisions. Under these constraints, the senior executives will make more rational decisions that favor corporate benefits and the interests of shareholders.
Hence, the influence of executive power on entrepreneurship can be summed up as: the principal-agent problem is mitigated by the incentive effect of control power and the constraints of the power allocation process, which promotes the forge of entrepreneurship. According to the Upper Echelons Theory, the senior executives with entrepreneurial spirit tend to use their control power to create corporate value, rather than seeking for private benefits [10, 11]. Compared to penalties against agency acts, granting power and trust to senior executives can effectively motivate them to invest more for the long-term benefits of their company, and maximize the utility of entrepreneurs. On this basis, the following hypothesis was put forward:

H1. Executive power has a significant positive impact on entrepreneurship.

\subsection{Business environment and entrepreneurship}

The theory of institutional change indicates that, the decisions of entrepreneurs concerning company operation depend on the external environment. If the economy policy is uncertain, companies will be reluctant to make investment; if the business environment is uncertain, companies need to spend more on nonproduction activities; if the trade environment is uncertain, companies must pay a higher cost in transactions.

A good business environment can help entrepreneurs cope with various uncertainties. In a good business environment, a company enjoys a stable external environment and a low institutional and trade cost, and acts enthusiastically to pursue innovation [12]. Nonetheless, the business environment, similar to economy, law, and the market, is developed in an unbalanced manner across China. The imbalance might hinder the nurture of entrepreneurship.

So far, there has been little report on how business environment affects entrepreneurship. The few relevant studies focus on a single angle, such as the protection of property rights, government intervention, and degree of marketization. In the real world, however, entrepreneurship could be influenced by the market, the legal system, and policies. The business environment is an organic system with multiple interactive dimensions, including legalization level, government intervention, and market competition [13]. Therefore, the influence of business environment on entrepreneurship must be explored from each of the said dimensions, as well as their interactions.

On the legalization level, the legal environment guarantees the fairness of the market. Only if the legalization level is high and the protection of property rights is sound, can companies actively invest in technological innovation.

Under a perfect legal environment, the legitimate rights and interests of entrepreneurs will be fully protected, giving them a sense of security. Then, entrepreneurs will divert more resources to production and innovation, because the legal system protects them from possible risks in innovation. If the legal environment is poor (e.g. lack of effective protection of property rights), the entrepreneurs will rush to launch immature technologies to seize market opportunities. This will waste social resources and disrupt the competition between innovators.

Thus, a sound legal environment, featuring the perfect protection of property rights, can reduce the innovation risk, safeguard innovation benefits, and crack down patent infringement. Then, entrepreneurs will not worry about the 
negative consequences of innovation investment [14]. On this basis, the following hypothesis was put forward:

$\mathrm{H} 2$. Legalization level promotes entrepreneurship in a region.

On government intervention, a sound business environment usually has a limited degree of government intervention. In a highly competitive market, entrepreneurs can allocate production factors independently, and seize market opportunities to drive the growth of their company. In the presence of excessive government intervention, many entrepreneurs will turn to the government for resources, rather than obtain resources through market means. Murky transactions and market chaos will inevitably ensue. Then, trade will become more costly, the benefits of innovation more uncertain, and the growth of entrepreneurship will be daunted.

To make matters worse, it is difficult for the government to evaluate the capability of each company, and provide support to those with the greatest potential, owing to supervision cost and information asymmetry. To win government subsidies, companies will compete to liaise with the government, sowing the risk of collusion between businessmen and politicians [15]. After receiving the subsidies, companies might expand production scale instead of improving product quality. This will crowd out the companies that truly seek technological innovation [16]. Consequently, under China's economic system, excessive government intervention will hinder the nurture of entrepreneurship. On this basis, the following hypothesis was put forward:

H3. Government intervention inhibits entrepreneurship in a region.

On market competition, the agency problem within a company can be effectively alleviated, when the management performance is fully disclosed. The disclosure, which is more likely under intense market competition, gives fully play to entrepreneurship.

To a certain extent, market competition lowers the agency cost of companies. Through market competition, every company is forced to disclose the performance of its management. Thus, external investors can know the ability and efforts of the management well, and supervise the senior executives more effectively. Besides, market competition complicates the external environment, and requires senior executives of every company to improve their ability and skills [17]. To survive the competition, all companies will engage in innovation more proactively.

In a region with fierce market competition, the market has the say in resource allocation. Entrepreneurs must summon external resources through market means. In this case, senior executives can utilize social capital more effectively, and commit innovative behaviors more willingly [18]. With the improvement of external governance and suppression, entrepreneurs will be encouraged to pursue innovation, and their company will plan and marketize more innovative products [19]. On this basis, the following hypothesis was put forward:

H4. Market competition promotes entrepreneurship in a region.

\subsection{The control power of senior executives, business environment and entrepreneurship}

During decision-making, senior executives can either take advantage of their control power to seek personal benefits, or step up the innovation of their company by creating an efficient operation environment [20]. To prevent the first type of behaviors, it is critical to improve corporate governance. Such behaviors can be curbed under a suitable external environment. For example, a good business environment can suppress the self-serving behaviors of senior executives, while promoting entrepreneurship: on the one hand, senior executives generally earn a high income in a good business environment, and have little desire to pursue private benefits; on the other hand, senior executives are not likely to possess excessive power, which is the basis for self-serving misconducts. Therefore, the reasonable allocation of control power needs to be combined with a good business environment to improve the entrepreneurship of senior executives.

As mentioned before, business environment can be broken down into three dimensions: legalization level, government intervention, and market competition. On legalization level, a perfect legal environment restrains the misuse of power for personal gains, for better legal system and law enforcement means greater information symmetry [21]. On government intervention, the collusion between businessmen and politicians is less likely, when the government does not strongly intervene in the market. At this time, senior executives will focus more on production and innovation. On market competition, external investors can know the ability and efforts of senior executives in companies competing in the same field. To attract investment, the board and shareholders will step up the supervision of senior executives. On this basis, the following hypotheses were put forward:

H5. Legalization level positively regulates the influence of executive power on entrepreneurship.

H6. Government intervention negatively regulates the influence of executive power on entrepreneurship.

H7. Market competition positively regulates the influence of executive power on entrepreneurship.

\section{RESEARCH DESIGN}

\subsection{Samples and data}

In this paper, China's A-share listed companies in 20132018 are selected as samples. The original data were collected from the China Stock Market \& Accounting Research (CSMAR) Database and the Marketization Index of China's Provinces compiled by Fan Gang et al., and then preprocessed in four steps: First, the financial and insurance companies were removed; Second, the companies marked with delisting risk warning $(* \mathrm{ST})$, special treatment (ST), and particular transfer (PT) were excluded; Third, the companies with incomplete data were deleted; Fourth, the continuous variables were winsorized at $1 \%$ quantile to eliminate outliers. Through the preprocessing, a total of 13,572 samples were obtained for further analysis.

\subsection{Variable measurement}

(1) Explained variable

In this research, the only explained variable is entrepreneurship. It is widely agreed that the core of entrepreneurship is innovation. Thus, our empirical analysis focuses on the innovation aspect of entrepreneurship, and measures innovation with the ratio of research and development (R\&D) expenditure to sales [22]. 
(2) Explanatory variable

Executive power was taken as the explanatory variable, and measured by the method of Zhao et al. [23]. and Grinstei and Hribar [24]. Based on the structure of control power and ownership, executive power was split into five dimensions: Chief Executive Officer \& Chairman are the same person? (Same), Does the CEO work part time or full time? (PoF), the tenure of the CEO (Tenure), the number of senior executives (Number), and the degree of equity dispersion (Dispersion) (as shown in Table 1).

\section{(3) Moderator variable}

The business environment was adopted as the moderator variable. Specifically, the market competition dimension was measured by the Herfindahl-Hirschman index (HHI). The HHI value is negatively correlated with the intensity of market competition. The legalization level dimension was measured by the development of market intermediary organizations and legal system environment, mentioned in the Marketization Index of China's Provinces compiled by Fan Gang et al. The government intervention dimension was measured by the fiscal expenditure as a proportion of regional gross domestic product (GDP). The greater the proportion, the more intense the government intervention.
(4) Control variables

To better reflect the relationships among executive power, business environment, and entrepreneurship, the following control variables were added: company size, free cash flow, asset-liability ratio, executive salary, compensation control, return on equity, and ownership.

The definitions and measuring methods of all variables are listed in Table 1.

\section{EMPIRICAL RESULTS AND ANALYSIS}

\subsection{Descriptive statistics and correlation analysis}

Table 2 presents the descriptive statistics on all variables. It can be seen that, entrepreneurship maximized and minimized at 0.258 and 0.001 , respectively, with a mean of 0.045 and a standard deviation of 0.044 . Hence, different companies vary greatly in terms of entrepreneurship. Executive power maximized and minimized at 5 and 0 , respectively, with a mean of 2.534 and a standard deviation of 1.113 . This means the companies have a sharp difference in executive power.

Table 1. The definitions and measuring methods of variables

\begin{tabular}{|c|c|c|}
\hline Name & Symbol & Definition/measuring method \\
\hline \multirow{3}{*}{ Entrepreneurship } & & Explained variable \\
\hline & & Ratio of R\&D expenditure to sales \\
\hline & & Explanatory variable \\
\hline \multirow{5}{*}{ Executive power } & Same & $\mathrm{CEO}$ and Chairman are the same person? Yes, Same $=1$; No, Same $=0$. \\
\hline & PoF & Does the CEO work part time or full time? $\mathrm{Yes}, \mathrm{PoF}=1 ; \mathrm{No}, \mathrm{PoF}=0$ \\
\hline & Tenure & The tenure of the CEO; if the tenure is longer than 4 years, Tenure $=1$; otherwise, Tenure $=0$. \\
\hline & Number & The number of senior executives; if the number is greater than 7, Number $=1$; otherwise, Number $=0$. \\
\hline & Dispersion & $\begin{array}{l}\text { The degree of equity dispersion; if the ratio of the total equity of the } 2^{\text {nd }} \text { to } 10^{\text {th }} \text { largest shareholders to } \\
\text { the equity of the largest shareholder is greater than } 1 \text {, Dispersion }=1 \text {; otherwise, Dispersion }=0 . \\
\text { Executive power equals the sum of the above five dimensions. } \\
\text { Moderator variable }\end{array}$ \\
\hline Legalization level & & $\begin{array}{l}\text { Development of market intermediary organizations and legal system environment, mentioned in the } \\
\text { Marketization Index of China's Provinces compiled by Fan Gang et al. }\end{array}$ \\
\hline $\begin{array}{l}\text { Government } \\
\text { intervention }\end{array}$ & & Fiscal expenditure as a proportion of regional GDP \\
\hline \multirow{2}{*}{ Market competition } & & Reciprocal of HHI \\
\hline & & Control variables \\
\hline Company size & & The logarithm of the total asset \\
\hline Free cash flow & & The ratio of net operating cash flow to the total asset \\
\hline Asset-liability ratio & & The ratio of gross liabilities to the total asset \\
\hline Executive salary & & Ln $(1+$ The total salary of the top three senior executives / 3$)$ \\
\hline $\begin{array}{l}\text { Compensation } \\
\text { control }\end{array}$ & & $\begin{array}{c}\text { The mean compensation of the top three senior executives with the highest income as a proportion of } \\
\text { per capita compensation }\end{array}$ \\
\hline Return on equity & & The ratio of after-tax profit to the net asset \\
\hline Ownership & & $\begin{array}{l}\text { The ownership of the company; if it is owned by the state, Ownership=1; if it is owned privately, } \\
\text { Ownership }=0 .\end{array}$ \\
\hline
\end{tabular}

Table 2. The descriptive statistics of variables

\begin{tabular}{cccccc}
\hline Variable & Maximum & Minimum & Mean & Standard deviation & Observed value \\
\hline Entrepreneurship & 0.258 & 0.001 & 0.045 & 0.044 & 13,572 \\
Executive power & 5 & 0 & 2.534 & 1.113 & 13,572 \\
Legalization level & 26.24 & 1.77 & 12.885 & 6.385 & 13,572 \\
Government intervention & 0.437 & 0.121 & 0.192 & 0.064 & 13,572 \\
Market competition & 45.748 & 1.141 & 14.222 & 10.751 & 13,572 \\
Company size & 28.253 & 17.806 & 22.066 & 1.277 & 13,572 \\
Free cash flow & 0.661 & -0.762 & 0.045 & 0.070 & 13,572 \\
Asset-liability ratio & 2.861 & 0.008 & 0.398 & 0.201 & 13,572 \\
Executive salary & 16.950 & 0 & 13.233 & 0.895 & 13,572 \\
Compensation control & 110.869 & 0 & 7.173 & 6.553 & 13,572 \\
Return on equity & 1.126 & 0 & 0.040 & 0.081 & 13,572 \\
Ownership & 1 & 0 & 0.304 & 0.460 & 13,572 \\
\hline
\end{tabular}


Table 3. The correlation coefficients of the main variables

\begin{tabular}{|c|c|c|c|c|c|c|}
\hline & Entrepreneurship & $\begin{array}{c}\text { Executive } \\
\text { power }\end{array}$ & $\begin{array}{c}\begin{array}{c}\text { Legalization } \\
\text { level }\end{array} \\
\end{array}$ & $\begin{array}{l}\text { Government } \\
\text { intervention }\end{array}$ & $\begin{array}{c}\text { Market } \\
\text { competition }\end{array}$ & $\begin{array}{c}\text { Company } \\
\text { size }\end{array}$ \\
\hline Entrepreneurship & 1.000 & & & & & \\
\hline Executive power & $0.149^{* * *}$ & 1.000 & & & & \\
\hline Legalization level & $0.129^{* * * *}$ & $0.130^{* * * *}$ & 1.000 & & & \\
\hline Government intervention & $-0.046^{* * *}$ & $-0.137^{* * *}$ & $-0.412^{* * *}$ & 1.000 & & \\
\hline Market competition & $0.143^{* * *}$ & $0.031^{* * *}$ & $-0.098^{* * *}$ & $0.030^{* * *}$ & 1.000 & \\
\hline Company size & $-0.273^{* * * *}$ & $-0.107^{* * *}$ & $-0.044^{* * *}$ & $0.122^{* * * *}$ & $-0.140^{* * * *}$ & 1.000 \\
\hline Free cash flow & $-0.030^{* * * *}$ & 0.009 & $0.015^{*}$ & $-0.031^{* * *}$ & $0.044^{* * * *}$ & $0.039^{* * * *}$ \\
\hline Asset-liability ratio & $-0.307^{* * *}$ & $-0.141^{* * * *}$ & $-0.095^{* * *}$ & $0.093^{* * *}$ & $-0.149^{* * *}$ & $0.534^{* * *}$ \\
\hline Executive salary & $0.044^{* * * *}$ & $0.048^{* * *}$ & $0.156^{* * *}$ & $-0.012^{* * *}$ & $-0.028^{* * *}$ & $0.286^{* * * *}$ \\
\hline Compensation control & $-0.080^{* * * *}$ & $0.057^{* * * *}$ & 0.008 & $-0.036^{* * *}$ & -0.011 & $0.279^{* * *}$ \\
\hline Return on equity & 0.004 & $0.058^{* * *}$ & $0.035^{* * *}$ & $-0.057^{* * *}$ & $0.067^{* * *}$ & $-0.037^{* * *}$ \\
\hline \multirow[t]{2}{*}{ Ownership } & $-0.202^{\text {**** }}$ & $-0.304^{* * *}$ & $-0.214^{* * * *}$ & $0.219^{* * *}$ & $-0.063^{* * *}$ & $0.394^{* * *}$ \\
\hline & Free cash flow & $\begin{array}{c}\text { Asset-liability } \\
\text { ratio }\end{array}$ & $\begin{array}{c}\text { Executive } \\
\text { salary }\end{array}$ & $\begin{array}{c}\text { Compensation } \\
\text { control } \\
\end{array}$ & $\begin{array}{c}\text { Return on } \\
\text { equity }\end{array}$ & Ownership \\
\hline $\begin{array}{c}\text { Entrepreneurship } \\
\text { Executive power } \\
\text { Legalization level } \\
\text { Government intervention } \\
\text { Market competition } \\
\text { Company size }\end{array}$ & & & & & & \\
\hline Free cash flow & 1.000 & & & & & \\
\hline Asset-liability ratio & $-0.162^{* * * *}$ & 1.000 & & & & \\
\hline Executive salary & $0.100^{* * *}$ & $0.073^{* * *}$ & 1.000 & & & \\
\hline Compensation control & $0.137^{* * *}$ & $0.087^{* * * *}$ & $0.540^{* * *}$ & 1.000 & & \\
\hline Return on equity & $0.333^{* * *}$ & $-0.347^{* * *}$ & $0.097^{* * *}$ & $0.115^{* * *}$ & 1.000 & \\
\hline Ownership & $-0.015^{*}$ & $0.311^{* * *}$ & $0.033^{* * * *}$ & $-0.051^{* * *}$ & $-0.090^{* * *}$ & 1.000 \\
\hline
\end{tabular}

Note: $* * *, * *$, and $*$ are the significance levels of 1,5 , and $10 \%$, respectively; the bracketed values are t-values.

The maximum and minimum of legalization level, government intervention, and business environment were 26.24 and $1.77,0.437$ and 0.121 , and 45.748 and 1.141 , respectively. The results show that the regions of the selected companies have very different legalization levels and the business environments.

When it comes to the control variables, the maximum, minimum, and mean of company size were $28.253,17.806$, and 22.066, respectively, indicating a huge size difference between companies. The maximum, minimum, and mean of free cash flow were $0.661,-0.762$, and 0.045 , respectively. The maximum and minimum of asset-liability ratio were 2.861 and 0.008 , respectively. The statistics on the financial indices demonstrate the varied operating conditions of the companies. The maximum and minimum of executive salary and compensation control were 16.950 and 0 , and 110.869 and 0 , respectively, suggesting a marked discrepancy among the companies in the incentives for senior executives. Finally, the ownership averaged at 0.304 , that is, more than $30 \%$ of the selected companies are state owned.

Table 3 displays the correlations between the main variables. It can be observed that executive power has a significant positive correlation with entrepreneurship at $1 \%$ level, which verifies $\mathrm{H} 1$. The legalization level has a significant positive correlation with entrepreneurship at $1 \%$ level; government intervention has a significant negative correlation with entrepreneurship at $1 \%$ level; market competition has a significant positive correlation with entrepreneurship at $1 \%$ level. As a result, H2-H4 were proved valid.

Of course, the results of the correlation analysis are preliminary. Further regression analysis is needed to further confirm how executive power and business environment affect entrepreneurship, and how business environment regulates the influence of executive power over entrepreneurship.

\subsection{Influence of executive power on entrepreneurship}

As mentioned before, the influence of executive power on entrepreneurship was tested from five dimensions. Table 4 shows the correlation coefficients between entrepreneurship, executive power, and its five dimensions. It can be seen that executive power has a significant positive correlation with entrepreneurship at $1 \%$ level, that is, executive power has a significant positive impact on entrepreneurship (H1).

Among the five dimensions of executive power, Same, PoF, and Tenure have a significant positive correlation with entrepreneurship at $1 \%$ level, indicating that greater CEO power benefits the growth of entrepreneurship. Dispersion has a significant positive correlation with entrepreneurship, that is, a dispersed equity structure favors the nurture of entrepreneurship. Number has a significant negative correlation with entrepreneurship, suggesting that a large board often fail to reach a consensus on innovation.

On the control variables, company size, free cash flow, and asset-liability ratio have a significantly negative correlation with entrepreneurship at $1 \%$ level. Hence, large company, high free cash flow, and high asset-liability ratio all hinder the growth of entrepreneurship. The regression coefficient of executive salary was significantly positive at $1 \%$ level, while that of compensation control was significantly negative at $1 \%$ level. This means executive salary incentivizes entrepreneurship, while compensation control suppresses entrepreneurship. In addition, the regression coefficient of ownership was significantly negative at $1 \%$ level, indicating that the executive power in private companies has a greater incentive effect on entrepreneurship than that in state-owned companies. 


\subsection{Influence of business environment on entrepreneurship}

Through regression analysis, the results on how business environment affects entrepreneurship were obtained (as shown in Rows 2-4, Table 5). It can be found that the regression coefficient of government intervention was not significant, that is, the relationship between government intervention and entrepreneurship is not empirically supported. After adding legalization level, whose coefficient was significantly positive at $1 \%$ level, the coefficient of government intervention became significantly positive at $1 \%$ level. After adding market competition, whose coefficient was significantly positive at $1 \%$ level, the coefficients of government intervention or legalization level were not greatly changed. Therefore, entrepreneurship has no significant correlation with government intervention, but greatly promoted by legalization level and market competition. This means $\mathrm{H} 2$ and $\mathrm{H} 4$ hold, but $\mathrm{H} 3$ is invalid. As for the control variables, the significance and sign direction (positive/negative) of their correlation coefficients were basically the same as those in Table 4.

The above analysis shows that legalization level and market competition both positively affect entrepreneurship. In other words, a sound legal system, especially the perfect protection of property rights, motivates entrepreneurs to divert more resources to innovation; market competition can also arouse the enthusiasm of innovation among entrepreneurs, and thus contribute to the nurture of entrepreneurship. By contrast, there is no obvious correlation between government intervention and entrepreneurship. The possible reason is that excessive government intervention might overshadow the role of entrepreneurs, and government subsidies could make entrepreneurs more engaged in innovation.

Table 4. The correlation coefficients between entrepreneurship, executive power, and its five dimensions

\begin{tabular}{|c|c|c|c|c|c|c|}
\hline Variable & Executive power & Same & PoF & Tenure & Number & Dispersion \\
\hline Executive power & $\begin{array}{c}0.004^{* * *} \\
(10.00)\end{array}$ & $\begin{array}{c}0.005^{\text {**** }} \\
(6.70)\end{array}$ & $\begin{array}{c}0.003^{* * *} \\
(4.15)\end{array}$ & $\begin{array}{l}0.001^{* * * *} \\
(5.08)\end{array}$ & $\begin{array}{c}-0.001^{* * * *} \\
(-4.12)\end{array}$ & $\begin{array}{c}0.004^{* * *} \\
(10.17)\end{array}$ \\
\hline Company size & $\begin{array}{l}-0.004^{* * * *} \\
(-11.75)\end{array}$ & $\begin{array}{l}-0.004^{* * *} \\
(-10.79)\end{array}$ & $\begin{array}{l}-0.004^{* * * *} \\
(-11.69)\end{array}$ & $\begin{array}{l}-0.004^{* * * *} \\
(-11.95)\end{array}$ & $\begin{array}{l}-0.004^{* * * *} \\
(-10.72)\end{array}$ & $\begin{array}{l}-0.004^{* * * *} \\
(-11.25)\end{array}$ \\
\hline Free cash flow & $\begin{array}{c}-0.025^{* * *} \\
(-4.77)\end{array}$ & $\begin{array}{c}-0.026^{* * * *} \\
(-4.87)\end{array}$ & $\begin{array}{c}-0.026^{* * * *} \\
(-4.95)\end{array}$ & $\begin{array}{l}-0.026^{* * * *} \\
(-4.95)\end{array}$ & $\begin{array}{c}-0.026^{* * *} \\
(-4.86)\end{array}$ & $\begin{array}{c}-0.024^{* * * *} \\
(-4.48)\end{array}$ \\
\hline Asset-liability ratio & $\begin{array}{l}-0.054^{* * *} \\
(-24.23)\end{array}$ & $\begin{array}{l}-0.055^{* * *} \\
(-24.76)\end{array}$ & $\begin{array}{l}-0.055^{* * *} \\
(-24.66)\end{array}$ & $\begin{array}{l}-0.055^{* * * *} \\
(-24.53)\end{array}$ & $\begin{array}{l}-0.055^{* * *} \\
(-24.68)\end{array}$ & $\begin{array}{c}-0.054^{* * *} \\
(-24.03)\end{array}$ \\
\hline Executive salary & $\begin{array}{c}0.008^{* * *} \\
(17.48)\end{array}$ & $\begin{array}{l}0.008^{* *} \\
(17.62)\end{array}$ & $\begin{array}{l}0.008^{* * *} \\
(17.80)\end{array}$ & $\begin{array}{c}0.008^{* * * *} \\
(17.85)\end{array}$ & $\begin{array}{c}0.008^{* * *} \\
(17.87)\end{array}$ & $\begin{array}{c}0.008^{* * *} \\
(17.01)\end{array}$ \\
\hline Compensation control & $\begin{array}{l}-0.001^{* * * *} \\
(-11.12)\end{array}$ & $\begin{array}{l}-0.001^{* * * *} \\
(-11.07)\end{array}$ & $\begin{array}{l}-0.001^{* * * *} \\
(-10.88)\end{array}$ & $\begin{array}{l}-0.001^{* * * *} \\
(-11.07)\end{array}$ & $\begin{array}{l}-0.001^{* * * *} \\
(-10.82)\end{array}$ & $\begin{array}{c}-0.001^{* * * *} \\
(-11.15)\end{array}$ \\
\hline Return on equity & $\begin{array}{c}-0.048^{* * * *} \\
(-9.86)\end{array}$ & $\begin{array}{c}-0.048^{* * *} \\
(-9.97)\end{array}$ & $\begin{array}{c}-0.048^{* * * *} \\
(-9.83)\end{array}$ & $\begin{array}{c}-0.048^{* * * *} \\
(-9.65)\end{array}$ & $\begin{array}{c}-0.047^{* * * *} \\
(-9.65)\end{array}$ & $\begin{array}{c}-0.046^{* * *} \\
(-9.48)\end{array}$ \\
\hline Ownership & $\begin{array}{c}-0.007^{* * * *} \\
(-7.83)\end{array}$ & $\begin{array}{c}-0.008^{* * *} \\
(-9.12)\end{array}$ & $\begin{array}{c}-0.009^{* * * *} \\
(-10.11)\end{array}$ & $\begin{array}{c}-0.008^{* * * *} \\
(-10.19)\end{array}$ & $\begin{array}{c}-0.009^{* * * *} \\
(-9.97)\end{array}$ & $\begin{array}{c}-0.007^{* * *} \\
(-8.69)\end{array}$ \\
\hline Constant term & $\begin{array}{c}0.054^{* * *} \\
(6.21)\end{array}$ & $\begin{array}{c}0.053^{* * *} \\
(6.10)\end{array}$ & $\begin{array}{c}0.059^{* * * *} \\
(6.82)\end{array}$ & $\begin{array}{c}0.061^{* * * *} \\
(6.97)\end{array}$ & $\begin{array}{c}0.061^{* * * *} \\
(7.04)\end{array}$ & $\begin{array}{c}0.056^{* * *} \\
(6.51)\end{array}$ \\
\hline $\mathrm{R}^{2}$ & 0.153 & 0.149 & 0.148 & 0.148 & 0.148 & 0.153 \\
\hline F value & $310.13^{* * * *}$ & $302.07^{* * *}$ & $298.02^{* * *}$ & $299.26^{* * *}$ & $297.98^{* * *}$ & $310.63^{* * *}$ \\
\hline
\end{tabular}

Note: $* * *, * *$, and $*$ are the significance levels of 1,5 , and $10 \%$, respectively; the bracketed values are t-values; the data are the output of Stata.

\subsection{Regulation of business environment on the correlation between executive power and entrepreneurship}

All the selected companies were subject to regression analysis to disclose the regulating effect of business environment on the correlation between executive power and entrepreneurship. As can be seen from the results (as shown in Rows 5-7, Table 5), the correlation coefficient of Executive power * Legalization level was significant, suggesting that legalization level positively regulates the influence of executive power on entrepreneurship (H5). The correlation coefficient of Executive power * Government intervention was significant at $1 \%$ level, revealing that government intervention enhances the influence of executive power on entrepreneurship will be reinforced. This finding goes against H6. The correlation coefficient of Executive power * Market competition was significantly positive at $1 \%$ level, indicating that market competition positively regulates the influence of executive power on entrepreneurship (H7).
The above analysis shows that government intervention stimulates the enthusiasm of entrepreneurs about innovation, and enhances the innovation ability of companies. As an invisible hand, government intervention can guide the corporate innovation through the release of proper policies, solving the information asymmetry in innovation. Bai et al. [25] indicates that preferential tax policy of the government is an effective incentive for corporate innovation: companies strive to meet the policy requirement by investing in R\&D of innovative products, while tax preference replenishes the operation fund of companies. To promote regional entrepreneurship, the government should design policies that encourage and guide the innovation of regional enterprises. In addition, the above analysis also reflects that market competition, which reflects the degree of efforts of senior executives, facilitates the supervision of the behaviors of senior executives, and enables entrepreneurs to divert more market resources to innovation, thereby promoting the nurture of entrepreneurship. 
Table 5. The influence of business environment on entrepreneurship

\begin{tabular}{|c|c|c|c|}
\hline & $\begin{array}{l}\text { Government } \\
\text { intervention }\end{array}$ & $\begin{array}{c}\text { Legalization } \\
\text { level }\end{array}$ & $\begin{array}{c}\text { Market } \\
\text { competition }\end{array}$ \\
\hline $\begin{array}{l}\text { Government } \\
\text { intervention }\end{array}$ & $\begin{array}{l}0.004 \\
(0.65)\end{array}$ & & \\
\hline $\begin{array}{c}\text { Legalization } \\
\text { level }\end{array}$ & & $\begin{array}{c}0.001^{* * *} \\
(8.51)\end{array}$ & \\
\hline $\begin{array}{c}\text { Market } \\
\text { competition }\end{array}$ & & & $\begin{array}{c}0.001^{* * * *} \\
(13.06)\end{array}$ \\
\hline $\begin{array}{l}\text { Executive power } \\
\text { Interaction term }\end{array}$ & & & \\
\hline Company size & $\begin{array}{l}-0.004^{* * *} \\
(-11.50)\end{array}$ & $\begin{array}{l}-0.004^{* * * *} \\
(-12.05)\end{array}$ & $\begin{array}{l}-0.004^{* * *} \\
(-11.16)\end{array}$ \\
\hline Free cash flow & $\begin{array}{c}-0.026^{* * *} \\
(-4.91)\end{array}$ & $\begin{array}{c}-0.026^{* * *} \\
(-4.86)\end{array}$ & $\begin{array}{c}-0.028^{* * * *} \\
(-5.25)\end{array}$ \\
\hline $\begin{array}{l}\text { Asset-liability } \\
\text { ratio }\end{array}$ & $\begin{array}{l}-0.055^{* * *} \\
(-24.74)\end{array}$ & $\begin{array}{l}-0.054^{* * * *} \\
(-24.30)\end{array}$ & $\begin{array}{l}-0.052^{* * * *} \\
(-23.43)\end{array}$ \\
\hline Executive salary & $\begin{array}{l}0.008^{* * * *} \\
(17.84)\end{array}$ & $\begin{array}{l}0.008^{* * * *} \\
(15.78)\end{array}$ & $\begin{array}{l}0.007^{* * * *} \\
(15.73)\end{array}$ \\
\hline $\begin{array}{l}\text { Compensation } \\
\text { control }\end{array}$ & $\begin{array}{l}-0.001^{* * * *} \\
(-10.92)\end{array}$ & $\begin{array}{c}-0.001^{* * * *} \\
(-9.71)\end{array}$ & $\begin{array}{c}-0.001^{* * * *} \\
(-9.87)\end{array}$ \\
\hline Return on equity & $\begin{array}{c}-0.047^{* * * *} \\
(-9.73)\end{array}$ & $\begin{array}{c}-0.046^{* * * *} \\
(-9.57)\end{array}$ & $\begin{array}{c}-0.048^{* * * *} \\
(-9.87)\end{array}$ \\
\hline Ownership & $\begin{array}{l}-0.009^{* * * *} \\
(-10.81)\end{array}$ & $\begin{array}{l}-0.008^{* * * *} \\
(-9.39)\end{array}$ & $\begin{array}{c}-0.008^{* * * *} \\
(-9.16)\end{array}$ \\
\hline Intercept term & $\begin{array}{c}0.058^{* * *} \\
(6.71)\end{array}$ & $\begin{array}{l}0.058^{* * * *} \\
(7.10)\end{array}$ & $\begin{array}{c}0.048^{* * * *} \\
(5.45)\end{array}$ \\
\hline $\begin{array}{c}\mathbf{R}^{2} \\
\text { F value }\end{array}$ & $\begin{array}{c}0.147 \\
295.55^{* * *} \\
\end{array}$ & $\begin{array}{c}0.151 \\
271.12^{* * *}\end{array}$ & $\begin{array}{c}0.162 \\
265.01^{* * * *}\end{array}$ \\
\hline & $\begin{array}{l}\text { Executive power * } \\
\text { Legalization level }\end{array}$ & $\begin{array}{c}\text { Executive power * } \\
\text { Government intervention }\end{array}$ & $\begin{array}{c}\text { Executive power * } \\
\text { Market competition }\end{array}$ \\
\hline $\begin{array}{l}\text { Government } \\
\text { intervention }\end{array}$ & & $\begin{array}{c}-0.056^{* * *} \\
(-4.28)\end{array}$ & \\
\hline $\begin{array}{c}\text { Legalization } \\
\text { level }\end{array}$ & $\begin{array}{l}0.001^{*} \\
(1.87)\end{array}$ & & \\
\hline $\begin{array}{c}\text { Market } \\
\text { competition }\end{array}$ & & & $\begin{array}{c}0.001^{* *} \\
(3.50)\end{array}$ \\
\hline Executive power & $\begin{array}{l}0.002^{* * *} \\
(3.33)\end{array}$ & $\begin{array}{c}-0.002^{*} \\
(-1.74)\end{array}$ & $\begin{array}{c}0.002^{* * *} \\
(4.07)\end{array}$ \\
\hline Interaction term & $\begin{array}{l}0.001 \\
(2.13)\end{array}$ & $\begin{array}{c}0.027^{* * * *} \\
(5.37)\end{array}$ & $\begin{array}{c}0.001^{* * * *} \\
(4.57)\end{array}$ \\
\hline Company size & $\begin{array}{l}-0.004^{* * *} \\
(-12.01)\end{array}$ & $\begin{array}{l}-0.004^{* * * *} \\
(-11.80)\end{array}$ & $\begin{array}{c}-0.004^{* * *} \\
(-10.99)\end{array}$ \\
\hline Free cash flow & $\begin{array}{c}-0.025^{* * *} \\
(-4.78)\end{array}$ & $\begin{array}{c}-0.025^{* * *} \\
(-4.70)\end{array}$ & $\begin{array}{c}-0.027^{* * * *} \\
(-5.12)\end{array}$ \\
\hline $\begin{array}{c}\text { Asset-liability } \\
\text { ratio }\end{array}$ & $\begin{array}{c}-0.053^{* * * *} \\
(-23.96)\end{array}$ & $\begin{array}{c}-0.054^{* * * *} \\
(-24.16)\end{array}$ & $\begin{array}{c}-0.052^{* * * *} \\
(-23.44)\end{array}$ \\
\hline Executive salary & $\begin{array}{c}0.007^{* * * *} \\
(15.89)\end{array}$ & $\begin{array}{c}0.008^{* * * *} \\
(17.35)\end{array}$ & $\begin{array}{c}0.008^{* * * *} \\
(17.61)\end{array}$ \\
\hline $\begin{array}{c}\text { Compensation } \\
\text { control }\end{array}$ & $\begin{array}{c}-0.001^{* * * *} \\
(-10.26)\end{array}$ & $\begin{array}{l}-0.001^{* * * *} \\
(-11.09)\end{array}$ & $\begin{array}{c}-0.001^{* * * *} \\
(-11.21)\end{array}$ \\
\hline Return on equity & $\begin{array}{c}-0.047^{* * * *} \\
(-9.81)\end{array}$ & $\begin{array}{c}-0.047^{* * * *} \\
(-9.81)\end{array}$ & $\begin{array}{l}-0.049^{* * * *} \\
(-10.15)\end{array}$ \\
\hline Ownership & $\begin{array}{c}-0.006^{* * *} \\
(-6.41)\end{array}$ & $\begin{array}{c}-0.007^{* * * *} \\
(-7.59)\end{array}$ & $\begin{array}{c}-0.007^{* * * *} \\
(-7.98)\end{array}$ \\
\hline Intercept term & $\begin{array}{c}0.060^{* * * *} \\
(6.84)\end{array}$ & $\begin{array}{c}0.066^{* * * *} \\
(7.27)\end{array}$ & $\begin{array}{c}0.044^{* * *} \\
(4.97)\end{array}$ \\
\hline $\begin{array}{c}\mathbf{R}^{2} \\
\text { F value } \\
\end{array}$ & $\begin{array}{c}0.156 \\
250.01^{* * * *}\end{array}$ & $\begin{array}{c}0.155 \\
251.71^{* * * *} \\
\end{array}$ & $\begin{array}{c}0.162 \\
265.99^{* * * *} \\
\end{array}$ \\
\hline
\end{tabular}

Note: $* * *, * *$, and $*$ are the significance levels of 1,5 , and $10 \%$, respectively; the bracketed values are $\mathrm{t}$-values; the data are the output of Stata. 
Table 6. The regulation of interaction terms of business environment on the correlation between executive power and entrepreneurship

\begin{tabular}{|c|c|c|c|}
\hline & $\begin{array}{c}\text { Executive power } \\
\text { *Legalization level* } \\
\text { Government intervention }\end{array}$ & $\begin{array}{c}\text { Executive power * } \\
\text { Legalization level * } \\
\text { Market competition } \\
\end{array}$ & $\begin{array}{c}\text { Executive power } * \\
\text { Government intervention } \\
* \text { Market competition } \\
\end{array}$ \\
\hline Executive power & $\begin{array}{l}0.001 \\
(0.73)\end{array}$ & $\begin{array}{l}0.002^{*} \\
(1.81)\end{array}$ & $\begin{array}{l}-0.001 \\
(-1.30)\end{array}$ \\
\hline Legalization level & $\begin{array}{c}-0.001 * * \\
(-2.35)\end{array}$ & $\begin{array}{l}-0.001 \\
(-1.28)\end{array}$ & \\
\hline Government intervention & $\begin{array}{c}-0.074 * * * \\
(-3.46)\end{array}$ & & $\begin{array}{l}-0.019 \\
(-0.90)\end{array}$ \\
\hline Market competition & & $\begin{array}{l}-0.001 \\
(-1.41)\end{array}$ & $\begin{array}{l}0.001 * * * \\
\quad(3.15)\end{array}$ \\
\hline $\begin{array}{c}\text { Executive power } * \text { Legalization } \\
\text { level }\end{array}$ & $\begin{array}{c}-0.001 * * * \\
(-2.81)\end{array}$ & $\begin{array}{l}0.001 \\
(1.13)\end{array}$ & \\
\hline $\begin{array}{c}\text { Executive power * Government } \\
\text { intervention }\end{array}$ & $\begin{array}{l}-0.005 \\
(-0.53)\end{array}$ & & $\begin{array}{c}0.016 * * \\
(1.96)\end{array}$ \\
\hline $\begin{array}{c}\text { Executive power * Market } \\
\text { competition }\end{array}$ & & $\begin{array}{l}0.001 \\
(1.35)\end{array}$ & $\begin{array}{l}-0.000 \\
(-0.90)\end{array}$ \\
\hline $\begin{array}{c}\text { Legalization level * Government } \\
\text { intervention }\end{array}$ & $\begin{array}{c}0.005^{* *} \\
(2.28)\end{array}$ & & \\
\hline $\begin{array}{c}\text { Legalization level * Market } \\
\text { competition }\end{array}$ & & $\begin{array}{l}0.001 * * \\
(3.42)\end{array}$ & \\
\hline $\begin{array}{c}\text { Government intervention } * \\
\text { Market competition }\end{array}$ & & & $\begin{array}{c}-0.003 * * \\
(-2.40)\end{array}$ \\
\hline $\begin{array}{l}\text { Executive power *Legalization } \\
\text { level* Government intervention }\end{array}$ & $\begin{array}{l}0.004 * * * \\
(4.76)\end{array}$ & & \\
\hline $\begin{array}{l}\text { Executive power * Legalization } \\
\text { level } * \text { Market competition }\end{array}$ & & $\begin{array}{l}0.000 \\
(1.55)\end{array}$ & \\
\hline $\begin{array}{l}\text { Executive power * Government } \\
\text { intervention * Market competition }\end{array}$ & & & $\begin{array}{c}0.001 * \\
(1.67)\end{array}$ \\
\hline Intercept term & $\begin{array}{l}0.095 * * * \\
(9.49)\end{array}$ & $\begin{array}{l}0.053 * * * \\
(5.79)\end{array}$ & $\begin{array}{c}0.047 * * * \\
(4.85)\end{array}$ \\
\hline R2 & 0.176 & 0.170 & 0.164 \\
\hline F value & $209.99 * * *$ & $200.98 * * *$ & $192.84 * * *$ \\
\hline
\end{tabular}

Note: $* * *, * *$, and $*$ are the significance levels of 1,5 , and $10 \%$, respectively; the bracketed values are $t$-values; the data are the output of Stata.

\subsection{Further regression analysis}

The business environment encompasses three dimensions that affect corporate production and operation. The interaction among these dimensions might regulate the relationship between executive power and entrepreneurship. As shown in Table 6, the regression coefficient of Executive power * Legalization level * Government intervention was significantly positive at $1 \%$ level, that is, the interaction between legalization level and government intervention positively regulates the incentive effect of executive power on entrepreneurship. The regression coefficient of Executive power * Legalization level * Market competition was positive but not significant, suggesting that the interaction between legalization level and market competition does not greatly affect the relationship between executive power and entrepreneurship. The regression coefficient of Executive power * Government intervention * Market competition was significant at $1 \%$ level, indicating that the interaction between government intervention and market competition positively regulates the incentive effect of executive power on entrepreneurship.

To sum up, the interaction between government intervention and legalization level, as well as that between government intervention and market competition, have a positive influence on the relationship between executive power and entrepreneurship. This finding sheds light on several matters. First, the business environment, as an organic whole of various elements, amplifies the incentive effect of executive power on entrepreneurship, owing to the interaction between its dimensions. Second, government intervention stands out from the dimensions of business environment for its significant regulating effect on the relationship between executive power and entrepreneurship. In China, social stability and economic growth are two key metrics in the performance appraisal of government officials. Hence, the local government is motivated to improve the legalization level and business environment. Under the current economic system of China, the government should roll out suitable policies to guide and adjust the innovation of companies, and make up for the market information asymmetry in many innovation activities. The government could promote the nurture of entrepreneurship through many indirect channels, such as improving the legal system to protect the legitimate rights and interests of entrepreneurs, and building a perfect market mechanism.

\section{CONCLUSIONS}

First, executive power has a significantly positive influence on entrepreneurship. Apart from regular salary, the benefits brought by control power can meet the demands of entrepreneurs, and reward them in the form of human capital. Moreover, the dynamic allocation of control power can restrain the self-serving behaviors of senior executives by 
optimizing the psychological cognitions and values of managers on company decisions.

Second, high legalization level and intense market competition benefit the nurture of entrepreneurship. A high legalization level reduces the innovation risks faced by entrepreneurs, and lowers the risks of exchanging innovation profits for companies. As a result, entrepreneurs will be willing to divert more resources to production and innovation. Intense market competition allows external investors to know the ability and efforts of senior executives in companies competing in the same field. To attract investment, the board and shareholders will step up the supervision of senior executives. Furthermore, entrepreneurs must summon external resources through market means, and become less reluctant in the pursuit of innovation.

Third, high government intervention and intense market competition greatly amplifies the incentive effect of executive power on entrepreneurship. The interaction between government intervention and market competition, as well as that between government intervention and legalization level, also magnifies that effect. Therefore, the government must design its intervention measures more rationally to bolster entrepreneurship.

There are several limitations of this research. First, this paper only selects the data on China's A-share listed companies, without considering the companies listed elsewhere or not listed. Hence, the research results might not apply to all companies. Second, the index selection needs to be further improved. In terms of entrepreneurship, the empirical analysis focuses solely on the innovation aspect. But entrepreneurship might cover many other aspects. In terms of business environment, the sum of the three dimensions, namely, legalization level, government intervention, and market competition, is not necessarily synonymous with business environment. In the future, it is necessary to investigate the data of other listed companies and non-listed companies, and to select even more indices for entrepreneurship and business environment.

\section{ACKNOWLEDGMENT}

This work was supported by Humanities and Social Sciences Fund of the Ministry of Education under the project "Corruption of Senior Executives in State-Owned Companies: Entrepreneur Incentive Paradox Under the Return of Control Power" (Grant No.: 18YJA630142), National Social Sciences Fund of China under the project "Double-Helix Driving Mechanism, Route and Countermeasures of Entrepreneurship Cultivation in the New Era" (Grant No. 18VSJ084), and Philosophy and Social Sciences Fund, Shanxi Province, China under the project "Normalizing Construction of Board of Directors in State-Owned Companies in Shanxi Under MixedOwnership Reform” (Grant No.: 2019B111).

\section{REFERENCES}

[1] Li, H., Yang, Z., Yao, X., Zhang, H., Zhang, J. (2012). Entrepreneurship, private economy and growth: Evidence from China. China Economic Review, 23(4): 948-961. https://doi.org/10.1016/j.chieco.2012.04.015

[2] Estrin, S., Tian, L. (2005). Retained state shareholding in Chinese PLCs: Does government ownership reduce corporate value? CEPR Discussion Papers, 36(1): 74-89. https://doi.org/10.1016/j.jce.2007.10.003

[3] Magee, J.C., Smith, P.K. (2013). The social distance theory of power. Personality and Social Psychology Review, 17(2): 158-186.

https://doi.org/10.1177/1088868312472732

[4] Hambrick, D.C. (2007). Upper echelons theory: An update. Academy of Management Review, 32(2): 334343. https://doi.org/10.5465/amr.2007.24345254

[5] Smith, A., Houghton, S.M., Hood, J.N., Ryman, J.A. (2006). Power relationships among top managers: Does top management team power distribution matter for organizational performance? Journal of Business Research, 59(5): 622-629. https://doi.org/10.1016/j.jbusres.2005.10.012

[6] Huang, Q.H. (2000), Control rights as incentive and constraint factor of entrepreneurs: Theoretical analysis and practical explanation significance. Economic Research Journal, 46(1): 41-47.

[7] Delgado, M., Porter, M.E., Stern, S. (2010). Clusters and entrepreneurship. Journal of Economic Geography, 10(4): 495-518. https://doi.org/10.1093/jeg/lbq010

[8] Stulz, R. (1990). Managerial discretion and optimal financing policies. Journal of financial Economics, 26(1): 3-27. https://doi.org/10.1016/0304-405X(90)90011-N

[9] Bertrand, M., Schoar, A. (2003). Managing with style: The effect of managers on firm policies. The Quarterly journal of Economics, 118(4): 1169-1208. https://doi.org/10.1162/003355303322552775

[10] Eisenhardt, K.M., Bourgeois III, L.J. (1988). Politics of strategic decision making in high-velocity environments: Toward a midrange theory. Academy of Management Journal, 31(4): 737-770. https://doi.org/10.5465/256337

[11] O'Neill, T.A., Allen, N.J., Hastings, S.E. (2013). Examining the "pros" and "cons" of team conflict: A team-level meta-analysis of task, relationship, and process conflict. Human Performance, 26(3): 236-260. https://doi.org/10.1080/08959285.2013.795573

[12] Yu, W.C., Liang, P.H. (2019). Uncertainty, business environment and private enterprises' vitality. China Industrial Economics, 36(11): 136-154. https://doi.org/10.19581/j.cnki.ciejournal.2019.11.008

[13] Lou, C.W., Zhang, G.Y. (2018). Research on the business environment from the perspective of governance: Internal logic and construction ideas. Journal of Liaoning University (Philosophy and Social Sciences $\quad$ Edition), 46(2): 59-65. https://doi.org/10.3969/j.issn.1002-3291.2018.02.008

[14] Xu, H. (2018). Typical mechanism of institutional environment affects technological innovation: theoretical interpretation and spatial test. Nankai Economic Studies, 34(5): 133-154.

[15] Dosi, G., Marengo, L., Pasquali, C. (2006). How much should society fuel the greed of innovators? On the relations between appropriability, opportunities and rates of innovation. Research Policy, 35(8): 1110-1121. https://doi.org/10.1016/j.respol.2006.09.003

[16] Zucker, L.G., Darby, M.R. (2007). Star scientists, innovation and regional and national immigration. National Bureau of Economic Research, No. w13547.

[17] Christie, A.A., Joye, M.P., Watts, R.L. (2003). Decentralization of the firm: Theory and evidence. Journal of Corporate Finance, 9(1): 3-36. https://doi.org/10.1016/S0929-1199(01)00036-0 
[18] Li, Y., Peng, M.W. (2008). Developing theory from strategic management research in China. Asia Pacific Journal of Management, 25(3): 563-572. https://doi.org/10.1007/s10490-007-9083-y

[19] Harms, R. (2013). 1. From Entrepreneurial Orientation to Performance: Inside the black box of corporate entrepreneurship. M@n@gement, 16(4): 410-421. https://doi.org/10.3917/mana.164.0410

[20] Wei, X.H., Liu, Y.M., Yue, L.Q. (2015). The impact of top management team power disparity on firm innovation intensity: Moderated mediating effect. Nankai Business Review, 18(3): 24-33. https://doi.org/10.3969/j.issn.1008-3448.2015.03.004

[21] Dyck, A., Zingales, L. (2004). Private benefits of control: An international comparison. The Journal of Finance, 59(2): 537-600. https://doi.org/10.1111/j.15406261.2004.00642.x
[22] Atanassov, J., Nanda, V.K., Seru, A. (2007). Finance and innovation: The case of publicly traded firms. Ross School of Business Paper, (970): 1-48. https://doi.org/10.2139/ssrn.740045

[23] Zhao, C., Yang, D.M., Cai, W. (2015). Administrative power, control power and management corruption in stata-owned enterprises. Journal of Finance and Economics,41(5): 78-89.

[24] Grinstein, Y., Hribar, P. (2004). CEO compensation and incentives: Evidence from M\&A bonuses. Journal of Financial Economics, 73(1): 119-143. https://doi.org/10.1016/j.jfineco.2003.06.002

[25] Bai, X.Y., Wang, Y.Y., Su, X. (2019). R\&D subsidies or tax incentives: An empirical analysis of government intervention on enterprise innovation performance and innovation quality. Scientific Research Management, 40(6): 9-18. 